\title{
Building Sportivity Through Appreciation of Tradition Peresean in Sasak Tribe Lombok
}

\author{
Elnang Soewena ${ }^{1 *}$ Hadjar Pamadhi ${ }^{1 * *}$ Santriawan Azmi ${ }^{1 * * *}$ \\ ${ }^{1}$ Arts Education of PostGraduate Program, Yogyakarta State University, Yogyakarta, Indonesia \\ ${ }^{*}$ Corresponding author. Email: elnangsoewena4@gmail.com \\ **Corresponding author.Email: hpamadhi@uny.ac.id \\ ${ }^{* * *}$ Corresponding author.Email: santriawanazmi@gmail.com
}

\begin{abstract}
Ethnographic research is an in-depth study of natural behavior in a culture that aims to analyze and interpret elements of a cultural group in society. Data in the form of observations, interviews, surveys, and analyzes of written material or recordings were then analyzed using content analysis where the results of the study showed that through appreciation of the Peresean tradition in Sasak tribe Lombok, it can reveal the value of sportsmanship which is reflected in the attitude and behavior of the pereseanto show authority. and recognizing the superiority of the opponent and accepting defeat with a fairness.
\end{abstract}

Keywords-Ethnographic, Content analysis, sportsmanship, tradition of Sasak peresehan

\section{INTRODUCTION}

Lombok is an island with an area of 4,700 square kilometers located in east of Bali Island. Lombok Island is one of the two main islands, which makes up the province of Nusa Tenggara Barat. Lombok has a wide range of arts and cultures. The various cultures can be found in Lombok. One of the important elements in the cultural system is art, because through arts, human beings are able to obtain channels to express experiences of senses and ideas that educate their inner life. In other words, art is one type of human needs associated with the disclosure of a sense of beauty.

The sasak community on the Lombok island of Nusa Tenggara Barathas a cultural heritage called peresean. Peresean is a Lombok people's entertainment that leads to the prominence of agility for the culprit. Peresean is played in pairs consisting of two or three pairs. The clothes used in this dance aresapuk (headbands), long cloth to tie the waist called bebet and long sarongs, and each dancer is not allowed to wear clothes and footwear such as shoes or sandals. Sportsmanship values, selfdefense skills are highly respected by every player in a peresean match and lead by a referee called pekembar. This peresean game depicts the courage and agility of the ancient youths when fighting against the enemy.

This peresean game uses several tools, including the following: Each pepadu (fighter) who will compete brings an ende (shield ) held by the other hand, and next to holding a punch made of a penjalin/penyalin (rattan). This peresean game is led by several referees, which consists of two pekembarsedi (edge referees) who number two to four people and a single tengaq (middle referee) totaling one person. This pekembar sedi is tasked with competing (choosing) the pair who will fight, while the pekembar tengaq (middle referee) is in charge of leading the game, in general this peresean game lasts for five battles (rounds). In this game, the pepadu are bound by awiq-awiq (rules) which become the handle in playing the game. Awiq-awiq (regulation) in the form of prohibition of hitting the waist down is prohibited from kicking and punching, cannot nujah(stab) and bleed in the head of one of the fighters means the game is over. Usually awiq-awiq is explained by the pekembar tengaq before the fighter just before the game starts.

Fostering the value of sportsmanship is a very important thing to be instilled early on in each individual so that everyone has a sporty attitude in him, namely the attitude of being willing to accept something openly. Accept defeat or lack of self. Instead, you want to accept and acknowledge the strengths and advantages of others.

The social and cultural phenomena around us also prove that there is an unsportsmanlike attitude to respond to something. Many people find it difficult to accept defeat from others. Similarly, accepting the strengths and advantages of others in a competition or competition. This tends to cause social conflict with outsiders.

In sociology studies, what is meant by value is the core value of the community. This core value is quoted by each individual or group of individuals whose numbers are quite large. These people really value that value and become one of the determining factors. one of the behaviors because of that cultural value serves as the highest guideline for human behavior [1].

Once the importance of sportsmanship values must be possessed by everyone, it is expected that through the appreciation of the tradition of the Lombok sasak tribe, it is expected to foster sportsmanship in order to instill positive things for everyone who is the basic prerequisite for establishing a civil society. Through the values in the 
peresean match can be realized internally in the practice of everyday life.

In general, sportsmanship is identified as a behavior that shows respect and fairness towards others and the attitude of receiving well whatever the outcome of a match [2]. The National Collegiate Athletic Association (NCAA, in Jay.D Goldstein \& S. E Iso-Ahola [3]) defines "sportsmanship as behavior shown by athletes, coaches, administrators and spectators in athletic competitions. These behaviors are based on important values such as respect, fairness, adherence, honesty and responsibility.

The process of planting sporty values through appreciation of the Lombok sasak tribe is expected to teach various basic movement skills, techniques and strategies in the tradition of peresean, internalization of values (sportsmanship, fair play, cooperation, philosophical values contained in the tradition of peresean and others -other).

\section{METHOD}

The type of research in this study uses qualitative research methods with an ethnographic approach. Ethnography as a research method is a work to explore natural behavior in a culture that aims to analyze, and interpret elements of a cultural group in society [4]. The main purpose of an ethnographic research method is to understand a cultural perspective and its relation to people's lives. This method is used to examine the condition of the object of research, namely the existence of the tradition of peresean in Lombok society. Data in the form of observations, interviews, surveys, and analyzed using content analysis in which the study was an in-depth discussion of all forms of communication both newspapers, radio news, television advertisements and all other documentation materials related to the tradition of the Lombok sasak tribe.

\section{DISCUSION}

\subsection{Peresean Cultural Tradition in the Lombok Sasak Tribe Society}

According to the customary history of the island of Lombok this has been done since the time of the kingdom which is usually staged to entertain the king and also to find the best fighters in an empire, but now has become a very strong cultural arts scene on this island. Peresean used to be done by the people of Lombok in the past, namely sporting each other with rattan held in the dry season which aims to ask the rain for the creator.

Peresean is one of the many indigenous cultural traditions of the sasak tribe on the island of Lombok. The tradition of peresean is a traditional art of fighting between two fighters called pepadu, using a rattan as a hitter called a braid whose edges are covered with asphalt wrapping and crushed shard of very fine, and a shield as a protector called ende made of cowhide or buffalo skin. Pepadu is never prepared in advance as usual in other battles, because the spectators who are present can also take part in this fight, or the leader of the match called pekembar can directly appoint the candidate pepadu from the audience present when the battle event starts. at that time. And then the pekembar (referee) will find a balanced opponent for the fighter or pepadu. The number of pepadu(fighters) in this event is usually never limited, and the fight is carried out one on one lead by twopekembar namely the middle referee in charge of leading the match, and the side referee in charge of giving the score to the fighting partner. The fight in this event was done with a round system of 5 rounds, andpepaduwere only allowed to hit the opponent's upper body, namely the shoulders, back and head, and fighters should not hit the lower body of the opponent from the waist, thighs to feet. For the highest score in the battle this peresean is if one of the fighters manages to hit the opponent's head. If the limb of one of the fighters bleeds in the initial round, the fighter will be declared defeated and the fight is considered complete, or one of the fighters surrenders. But if the two fighters can survive until the 5th round is finished, then the winner is determined by the highest score given by the referee edge. To further increase the enthusiasm of the pepadu, this peresean tradition is usually accompanied by the traditional sasakgamelan music when the battle begins. Sometimes pepadu will dance to the gamelan rhythms played by the musicians. This event can indeed be said to be a very hard culture, because at this event the fighters will show a hit each other using rattan until one of the fighters gives off fresh blood from the limbs affected by rattan or braiding, but this peresean culture is one of the traditional cultures that very high up the value of sportsmanship, because even though they inside the arena hit each other fiercely until someone had to bleed, but after the match was over they hugged each other and outside the arena there was no revenge between them one bit. Although the tradition of peresean is a very hard traditional culture, but until now the cultural tradition of peresean is still preserved by the people of Lombok sasak tribe in order to test the courage or courage of sasak young men.

The peresean tradition program has been going on for generations since hundreds of years ago, and this traditional ritual peresean is usually held when the dry season arrives to summon rain. Peresean tradition or culture is very sacred by the sasak people on the island of Lombok, but because in accordance with the times, today the peresean tradition is held only at certain times ahead of special celebrations such as the celebration of the Independence Day of the Republic of Indonesia, Anniversary Regency / Municipality year on the island of Lombok or before the month of Ramadan. This peresean tradition was initially motivated by the emotional feeling of the kings of the past when they had to fight towards the battlefield to defeat their enemies. Therefore, peresean is also used as an arena to show or foster courage, agility and resilience in a battle. Blood dripping to the earth in a battle of peresean due to the slashing of a batter is also believed to be a symbol of the rain, so the more blood dripping, the more rain will drop. 


\subsection{Abbreviations and Acronyms}

Define abbreviations and acronyms the first time they are used in the text, even after they have been defined in the abstract. Abbreviations such as IEEE, SI, MKS, CGS, sc, dc, and rms do not have to be defined. Do not use abbreviations in the title or heads unless they are unavoidable.

The battle arena of the pepadu in peresean actually does not require a large place because it is only done by two players in one match. However, because it was witnessed by many people, the peresean location is generally held in the field or field.

The equipment used by a pepadu (player) is only two kinds, namely:

(1) a beater such as whip (whip) made of rattan or a braid about 50 centimeters wrapped in leather which sometimes is covered with asphalt wrapping and finely ground crushed glass.

(2) a shield or ende made of cow or buffalo skin as a protector and repellent of an opponent's attack.

To further enliven the atmosphere, peresean also features accompaniment music called peresean drum, consisting of: one gong, two drums, one petuk, one set of rencek / rincik, and one bamboo flute.

Gending peresean can be divided into three types, namely:

(1) Gending rangsang or gending ngadokang, played when the pekembar and the pengadok look for pepadu to be competed.

(2) Gending mayuang, is played as a sign that there are two pepadu people who are ready to do the peresean.

(3) Gending beradu played during the match with the aim of arousing the spirit of pepadu and the spectators who witnessed it.

\subsection{Rule of the Game}

Rules in peresean games are called awig-awig, including:

(1) using a round system of three to five rounds marked by the blowing of a whistle by a tengaq sheet.

(2) a pepadu can only hit the upper part of the body (head, back) and is prohibited from affecting the lower part of the body of the opponent (from the waist to the foot).

(3) using the value system provided by pekembarsedi twins if both pepadu can still survive and not bleed until the last round. However, if a pepadu has bled due to the opponent's rattan slash, then he is declared defeated and the fight is immediately stopped.

\subsection{Procedure for Playing Games}

Peresean game begins with choosing the pepadu from the audience. They (prospective pepadu) generally wear sapuq (headbands) from cloth, lereng leang (long cloth) and belts that are sometimes tucked in by badong or azimat (amuled) to guard themselves and or weaken opponents. There is a way to choose pepadu that is done directly by pekembar by looking for people who are balanced as opposed to match and some are chosen by pepadu by challenging other pepadu who are still in the crowd. During choosing pepadu, this is generally accompanied by gending peresean music with gending rangsangrhythm or gending ngadokang to make the atmosphere more festive.

If two pepadu people have been chosen, they will immediately enter the game arena while carrying rattan and ende (shield), as seen in Figure 1. The two of them then stand facing each other with a sheet between them to explain awig-awig or rules in the peresean, such as: how many rounds must be followed, the time of each round, things that should not be done during the fight, giving a value to the perceived blow valid, etc. which are technical implementation. After explaining awig-awig peresean, the pekembartengaq team then gave a signal with the whistle to immediately start the fight. While on the side of the arena, thepekembarsedi began to watch the course of the fight to give an assessment.

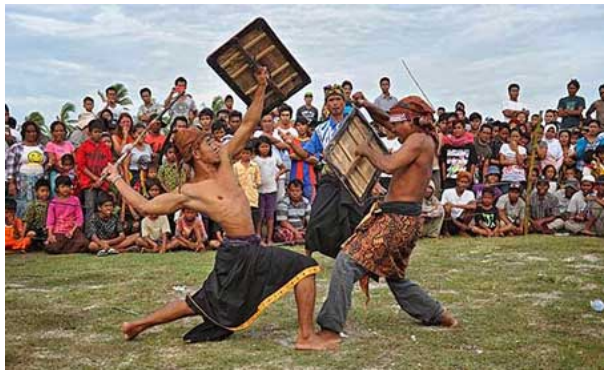

Figure 1 Peresean Game

A moment after the whistle sounded, the two pepadu will mutually "make each other" or attack each other using a rattan. They try to show the shrewdness of the attacking movement, fend off blows, and steal off in order to land the anchor right on the opponent's head and get a high score from the pekembar sedi. For some pepadu, especially those who are proficient, the game does not just use certain techniques and skills, but also the science of immunity and other mystical things.

If the time specified in one round ends, the pekembar tengaq will blow the whistle to give the pimps time to rest. This opportunity is used by pepadu to dance to the rhythm of gending peresean while restoring energy and analyzing the opponent's condition. In addition, rest periods are also used as an arena for snapping to weaken the mental and spirit of the opponent before the fight resumes. And, once the whistle is sounded again, the two pepadu fight again until the specified round ends. If both pepadu are equally able to survive, then the winner is determined by a score based on the assessment of the pekembar sedi. However, if a pepadu has bled due to a stabbing blow, the match is immediately stopped to maintain safety. Pepadu who succeed in making his opponent bleed is declared a winner and the fight ends with embracing each other as a sign of friendship. 
When one fight is over, the twins will look for other pimps who are still in the crowd for the fight. And so on until the whole pepadu has a turn to play or the time for organizing the event has ended.

\subsection{Equations Peresean Clothing}

In a traditional sasakperesean match, there is a traditional dress peresean which is also very guarded and must be fulfilled by the pepadu, pekembar or court, such as:

1. Sapuk / capuk with batik motif (headband from batik cloth)

2. Kereng (sarong).

3. Bebet (tenun ikat (weaving) that binds the kereng, usually tucked into a charm or magic charm as a pain reliever or build charisma and magical power between pepadu).

Some of the important elements above, both from clothing and gending and supporting arts, is a differentiator that the art of fighting peresean virility is not a street fight, wild fight or ferocity, but a culture and art that is very deep and contains elements of ancestors that are so profound in the sasak tribe.

\subsection{Building Sportivity through Appreciation of the Peresean Tradition}

Peresean tradition puts forward sportsmanship, having a sportsmanship for the younger generation is very important because sportsmanship is the values in building a dignified nation.

Sportivity is a major component of morality in peresean games. Shields and Bredemeier [5] argue that sportsmanship involves intense struggle for success, commitment to the spirit of play so that ethical standards will take precedence over strategic advantages when conflict. Sportive requires that the younger generation understand and obey not only the formal rules but also the rules of the game that are not written in the game peresean. Sportive means that all participants have a fair chance to pursue victory in competitive sports, have the ability to achieve victory through an elegant attitude. Sportive is a mental attitude that shows the dignity of knights in peresean games. Sportive values underlie the formation of attitudes, and then attitudes become the basis for behavior. sportsmanship is giving equal opportunities to win in competition. All of them must uphold the prevailing regulations and maintain friendship in the midst of the great spirit of competition, therefore in the eyes of the community it will have a high value. Sportive is an awareness that is always attached, that the competitor is a competing friend bound by sports fraternity. Sportive is a mental attitude that shows the dignity of a knight in sports. The value of sportsmanship underlies the formation of attitudes, and then attitudes become the basis of behavior. As a moral concept, sportsmanship contains respect for opponents as well as related self-esteem between the two parties looking at their opponents as partners. All and efforts and struggles are carried out based on moral standards that are lived by each side. Sportsmanship converges with the concept of friendship and respect for opponents when playing. Therefore, through the appreciation of the tradition of the Lombok sasak tribe, it is expected to familiarize and apply the value of sportsmanship which is reflected in the attitudes and behaviors of the peresean players to show authority and recognize the superiority of the opponent and accept defeat with a fairness.

\section{CONCLUSION}

The tradition of peresean is a traditional art battle between two fighters called pepadu, using a rattan as a bat and a shield as a protector called ende made of cowhide or buffalo skin. Peresean tradition puts forward sportsmanship, having a sportsmanship for the younger generation is very important because sportsmanship is the values in building a dignified nation. Therefore, through the appreciation of the tradition of the Lombok sasak tribe, it is expected to familiarize and apply the value of sportsmanship which is reflected in the attitudes and behaviors of the peresean players to show authority and recognize the superiority of the opponent and accept defeat with a fairness.

\section{REFERENCES}

[1] Koentjaraningrat, 1986. "Pengantar Ilmu Antropologi [Introduction to the Science of anthropology]." Cetakan ke-6. Jakarta: Aksara Baru.

[2] Beller, J. M., \& Stoll, S. K.. Sportsmanship: An antiquated concept?. Journal of Physical Education, Recreation \& Dance, 64(6), pp. 74-79. 1993. DOI : https://doi.org/10.1080/07303084.1993.1061000 9

[3] Goldstein, J. D., \& Iso-Ahola, S. E. Determinants of Parents' Sideline-Rage Emotions and Behaviors at Youth Soccer Games 1. Journal of Applied Social Psychology, 38(6),pp.1442-1462. 2008. DOI https://doi.org/10.1111/j.15591916.2008.00355.x

[4] Spradley, J. P., Elizabeth, M. Z., \& Amirudin. "Metode etnografi [Ethnographic methods]." 2009.

[5] Weinberg, R.S., \& Gould, D. Foundation of Sport and Exercise Psychology, 6E. Human Kinetics. 2014 